\title{
A content-based approach using the subprime crisis as portrayed in The Big Short
}

Claire Heuillard

\section{(2) OpenEdition}

1 Journals

Electronic version

URL: https://journals.openedition.org/asp/6107

DOI: 10.4000/asp.6107

ISSN: 2108-6354

\section{Publisher}

Groupe d'étude et de recherche en anglais de spécialité

\section{Printed version}

Date of publication: 1 November 2019

Number of pages: 90-102

ISSN: 1246-8185

\section{Electronic reference}

Claire Heuillard, "A content-based approach using the subprime crisis as portrayed in The Big Short", ASp [Online], 76 | 2019, Online since 01 November 2019, connection on 02 December 2021. URL: http://journals.openedition.org/asp/6107 ; DOl: https://doi.org/10.4000/asp.6107

This text was automatically generated on 2 December 2021.

Tous droits réservés 


\title{
A content-based approach using the subprime crisis as portrayed in The Big Short
}

\author{
Claire Heuillard
}

This report describes an ESP teaching module in financial English taught since the 2016-17 academic year at Panthéon-Assas University (Paris) in the third year of an economics and management Bachelor's programme. Claire Heuillard approaches the subprime crisis through a film, The Big Short (McKay 2015), inspired from Michael Lewis's bestseller, The Big Short - Inside the Doomsday Machine (Norton 2011), one of the best encapsulations of the latest bubble-and-crash episode in financial history. In her course design, C. Heuillard is treading both new and familiar territory. The novelty is that fully structured courses in financial English devoted to the subprime crisis are still thin on the ground. Because of its global magnitude and multifaceted consequences, the subprime boom and bust has attracted a lot of interest from ESP instructors teaching economics and finance learners; yet, long-term pedagogical applications - C. Heuillard's programme covers one semester - are still rare and her offer is welcome.

Still, in its philosophy, the approach is not without precedents and the author adds up to previous published contributions in financial English. These have been steered by similar considerations that are specific to financial specialisedness. In 2004, Van der Yeught also used a film emblematic of the October 1987 Wall Street crash (Stone, Wall Street 1987) to decipher the professional content of the American financial community in the context of the 1980s. In 2017, Marc Éline devoted a paper to Liar's Poker (Hodder and Stoughton, 1989), a previous bestseller by Michael Lewis. The book made its author famous and positioned him as an inside middleman with a talent to initiate the public into the arcane world of stock market battles and takeover raids. His Big Short does it again with the subprime crisis.

What all these approaches have in common is that courses in financial English have to be based on substantial professional content if communication exercises are to be relevant and meaningful. As a domain, finance is closely corseted by technical, institutional and historical constraints. Forgetting these generally leads any communicative task into disciplinary nonsense 
or professional irrelevance. C. Heuillard is also right in rooting her teaching in diachrony by proposing complementary explorations into major historical speculative bubbles. She does not mention the texts used as backups for these discoveries, but Mackay's Extraordinary Popular Delusions (Wordsworth 1995 [1841]) immediately comes to mind. It is a well-known classic of stock market culture which covers the Dutch "Tulipomania" (1635), the "South Sea Bubble" (England 1720) and the French "Mississippi Scheme" (1719-20). The report carefully details progression and assessment procedures, but, significantly, it opens on content-based instruction (CBI) and explains why this pedagogical position is best suited to the approach. From what precedes, readers will understand that I fully agree with this standpoint. I simply wish to elaborate on the CBI concept and explain why, in my view, it may be incomplete. C. Heuillard explains that "[t]he fact that students are given cognitively challenging material stimulates the adjacent learning process." Admittedly, the proposition is appealing, but any "cognitively challenging material" does not automatically trigger learner interest if the latter is not factored into the teaching situation in some way. For example, cognitively challenging material in English for physics or chemistry, although intrinsically "interesting", will presumably stimulate very little interest among students majoring in finance or history. The incompleteness of CBI is that it focuses on the object (content), but with no obvious link to the learning subject. Motivation implies some particular empathy between two connected instances, subject and object (content and learner). Content is not a bearer of motivation in itself and lacks in interface power.

That is the reason why I have suggested that "intentionality" may be a fitting notion to explain specialisedness (Van der Yeught 2016). "Intentionality" was introduced in modern philosophy by Brentano and Husserl in the $19^{\text {th }}$ century, and later refined by Sartre and Searle. It refers to "that capacity of the mind by which it is directed at, or about objects and states of affairs in the world" (Searle 2010: 25). As I see it, specialisedness is a variety of intentional mental states which is durably and selectively directed towards one same object for some particular purpose (desire or belief). The point I want to make is that intentionality contains both subject and object, and that "specialisation" relates both via some form of enduring and focused empathy. In theory, therefore, learners specialising in physics will feel motivation to learn more about it, be it through English or their native tongue. Of course, we all know that learners may enrol in subjects for which they have no disciplinary yearning; but in that case, although they belong to the LANSAD ${ }^{1}$ sector, they cannot be counted as "specialists" since they do not feature the corresponding intentionality. They simply fall out of the motivation issue as random cases that theories cannot take into account. In the Big Short module, feedback points to the contrary and indicates that content meets learners' expectations, a clear sign that specialised intentionality is at work and relates them both. (Michel Van der Yeught, Aix-Marseille Université)

1 Motivation in compulsory ESP courses is often lukewarm. At first sight the English classroom is not the natural habitat of students majoring in biology, economics or engineering. While students in higher education in France generally realize that proficiency in a foreign language can improve their perspectives of success on the job market, that extrinsic motivation is not necessarily sufficient to stimulate them to hone their language skills. Success also depends on the intrinsic motivation that comes from engaging in an activity for the pleasure of understanding or satisfying curiosity. As Ushioda remarks, "the language learner, unlike the researcher, seems unlikely to perceive the motivation for language learning to be wholly independent of the motivation (or lack of motivation) for other areas of learning" (1998: 83). The material through which students learn a language must be deemed relevant. In short, "Students are not motivated to learn unless they regard the material they are taught as worth learning" (Dörnyei \& Ushioda 2011: 116). 
2 This imperative to provide cognitively demanding material in order to stimulate motivation provides a strong case for content-based instruction (CBI) for ESP students. "Content" has been defined in a number of different ways. For Crandall \& Tucker, it refers to "academic subject matter" (Crandall 1990: 189) while for Genesee it can be extended to "include any topic, theme or non language issue of interest or importance to the learners" (Genesee 1994: 3). While the latter definition is particularly vast, it serves to highlight the need for course designers to seek out material that will genuinely engage learners. Essentially, the content-based classroom is a space where "language development and content development are not regarded in isolation from each other and there is a focus on the intersection of language, content and thinking objectives," (Mohan 1990: 113). Extensive content engages the learner while at the same time providing the necessary discourse for contextualized language learning and exploration. In short, CBI is at the junction between the need to learn language and the need to use language.

3 Two fundamental premises support the CBI approach in the ESP classroom. Firstly, proficiency in any foreign language requires a combination of knowledge of the appropriate linguistic forms as well as extended exposure to the living language. Since proficiency in academic contexts requires many years of study, it is not always possible to delay specialized content learning until academic proficiency has been achieved. Consequently, students need to acquire specialized knowledge while they are learning language. The second premise follows from the first: specialized content provides a genuine communicative context and therefore provides language learners with appropriate material for improving their language skills. As Eskey (1997: 133) points out "people do not learn languages and then use them, but [...] people learn languages by using them." Content provides the context for exchanging complex ideas articulated around the appropriate linguistic forms. The fact that students are given cognitively challenging material stimulates the adjacent learning process. Learning takes place when pre-existing knowledge is put into relation with new information, which leads to greater depth of processing, even if that new information is presented in a different language (Grabe \& Stoller 1997: 7). In the CBI classroom, the presentation of coherent and relevant information leads to deeper processing and deeper information processing leads to better learning.

4 This paper reports on an ESP course at Paris 2 University (Panthéon-Assas) implemented in the third-year of the Economics and Management Bachelor programs, which explores the subprime crisis using a content-based approach.

\section{Context}

The subprime crisis was more than a passing footnote in recent economic history. Its causes were rooted in the radical transformation that the financial sector underwent in the late 20th century; its consequences are still being felt today. Although understanding events requires knowledge of a certain number of financial instruments, the crisis is far more than a technical blip. It encapsulates a watershed moment in American civilization that can be explored as a complex interweaving of financial, economic, social and political events. The subprime crisis is not just about a fleeting meltdown of the US housing market; it also raises questions about social inequality, 
perverse incentives and the assessment of trickle-down economics. These are all compelling themes for the language classroom.

While all economics students have some knowledge of the causes and consequences of the subprime crisis, overall their understanding of the events and mechanisms that led the world economy to the brink of collapse is quite superficial. This course provides an opportunity for students to become familiar with the financial products that caused the market crash, but, more importantly, to learn about the background context that fuelled events and to engage in the debates surrounding the crisis that continue to resonate in US society today. Our approach was to explore this subject matter by blending cinema, journalism and economic analysis.

7 The guiding thread that runs through the course is the movie adaptation of Michael Lewis' book, The Big Short. The film is particularly well suited to the classroom as it manages to be entertaining and engaging, yet simultaneously seeks to inform its audience. The opening scenes sketch the historical context of the American bond market in the decades preceding the crisis while the ongoing narrative is frequently interrupted by characters delivering monologues about the workings of financial markets or products.

8 In other words, the "content" of this course is dual. Most obviously it includes the purely academic knowledge of the subprime crisis, yet it also extends to encompass exploration of the cinematographic representation of the various aspects of that crisis.

\section{Course objectives}

9 In addition to my language teaching credentials, I also hold a doctorate in Economics from Paris I University. Ever since first reading Lewis' The Big Short, I had been toying with the idea of using it in the classroom. When the film adaptation was first released I was immediately struck by how well-suited it was for the classroom and I got straight to work elaborating a syllabus.

The course was first implemented during the 2016-2017 university year, with an enrolment of 254, divided into tutorial groups limited to a maximum of 22 students. Although students range from A2 to $\mathrm{C} 2$ level, classes are not streamed and the vast majority falls within the B1-B2 range. The target level on completion of the course is a reinforced $\mathrm{B} 2+$ level. The weakest students will struggle to meet this goal, however, most of the enrolled students have already completed their first two years of undergraduate studies at Paris 2 University and therefore have already received two years of ESP instruction. A brochure providing all the basic material for the course, including syllabus outline, questions and weblinks is handed out to students during the first week of classes.

11 Alongside its aim of providing students with a motivating framework for contextualized language learning, the course has a general organizational aim as well as four specific learning objectives.

12 With regards to classroom organization, the course design's central goal is to encourage students to become autonomous learners. As the students reach the end of their undergraduate degree, some will be planning to pursue a master's degree, others to enter the job market. At this turning point in their lives, the course seeks to help students assume greater responsibility for learning outcomes by encouraging them to 
engage in constant interaction with each other instead of systematically seeking teacher feedback and student-teacher interactions.

In addition to this implicit goal, there are a number of course objectives explicitly defined in the syllabus. These objectives were designed to dovetail with students' professional goals. Many graduates from the Economics and Management program at Paris 2 seek to pursue a professional path in business rather than in research. Consequently, the English course focuses on skills that may be transferred to business contexts.

Firstly, students are made aware of the need to become more adept at recognizing and using appropriate language register. Outside of the classroom, many students depend on television series, YouTube channels and movies to improve their English skills. While this is a step in the right direction, overdependence on material from popular culture may foster a casual register instead of the formal or technical register that is expected in many business contexts. Starting on the first week of courses, students are reminded that whenever they communicate, whether in spoken or written form, they must always choose the register appropriate to their audience and purpose. The course seeks to develop awareness of three types of registers: casual, formal and academic.

The second aim is to improve students' Q\&A skills. Successfully asking pertinent questions or knowing how to answer questions are useful skills for meetings, conferences and presentations. Many of the activities proposed throughout the semester encourage direct interaction between students. The aim is to consolidate the ability to ask questions, clarify meaning and rephrase.

The third aim is to enrich technical vocabulary by fostering autonomy. At the end of each week's lesson, a list of useful vocabulary is provided in the course brochure. Students are expected to look up the meaning of these words on their own and be able to use them correctly during class discussions. In addition to adding these words to their vocabulary, active recycling of lexicon in the classroom provides an opportunity to consolidate correct pronunciation of these words, as well as eliminating mispronunciation of a number of transparent words that are repeated naturally throughout the course (e.g. crisis, agency, bank).

The course's fourth explicit aim is to improve students' understanding of the subprime crisis. Although the course's theme is of general interest to any economics student, the material is also complementary with a compulsory course in Monetary Economics and International Finance that many of the students must take to complete their degree.

\section{Course design}

The course was specifically designed for the Paris 2 calendar, which means a total of 19.5 hours of class time organized in thirteen 1.5 -hour lessons ${ }^{2}$. On the first day of classes, students are given the brochure for the entire semester, which includes the basic outline and material for each session. Each week a certain aspect of the crisis is explored. These themes include "Securitization", "Collateralized Debt Obligations and Credit Default Swaps" (CDO's and CDS's), "Short selling", the "Housing bubble", the "Complicity of the rating agencies", "Moral hazard and too big to fail", as well as "Ethics and the consequences of the subprime crisis". 

to prepare at home. Core material is provided by excerpts from Michael Lewis' book The Big Short and Joseph Stiglitz's Freefall, as well as passages from a macroeconomics textbook that addresses the subprime crisis. This core material is completed by recordings and documents from a wide variety of sources ranging from Nobel Prizewinning authors (e.g. Krugman's "The Conscience of a Liberal" column from the New York Times or a video interview of Robert Shiller) to more journalistic sources such as The Atlantic or Rolling Stone Magazine. week's theme and the lexicon necessary to explore relevant topics. A series of questions is provided in the brochure each week in order to help students navigate this material. led discussion. From the point of view of language acquisition, this part of the lesson belongs to the practice stage, as it provides students with an opportunity to compare their answers with those of the students leading the discussion, but also to adopt correct lexicon, structures and pronunciation.

3.2. The practice stage of the lesson continues during the second part of the lesson when excerpts from the film, The Big Short are viewed and discussed. All language classrooms at Paris 2 are equipped with an interactive screen, making the exercise easy to implement. The excerpts that are shown are legally available on Paramount Pictures' YouTube channel. Each clip is chosen for its relevance to the theme under study during a given week. The videos range in length from one minute to over seven minutes, which leaves scope for teachers to introduce diversity in the way the material is covered from one week to the next. These activities provide an opportunity to work on listening comprehension but also to explore the language used in various situations and highlight key pronunciation points.

Discussion of directorial choices and cinematic devices are an important aspect of this part of the lesson. At this point in the lesson, the content focus shifts away from economics to examine the movie's more artistic elements. The Big Short received the Oscar for best adaptation and the director was a contributing screenwriter. His choices in terms of soundtrack, editing, casting and use of devices such as breaking the fourth wall are not only interesting from an artistic standpoint, they also help communicate and convey meaning. For instance, the presence of the song Crazy in the background as Mark Baum learns how mortgage brokers in Florida vet their clients is not a random choice for the soundtrack, and the repeated shots of Wall Street's Charging Bull statue is open to interpretation, but clearly significant.

The videos also provide an interesting opportunity to explore the notion of register. For instance, using Margot Robbie in a bubble bath to explain mortgage-backed securities allows the director to catch the audience's attention to transmit information about a seemingly boring topic. More importantly, however, the intimate setting and Robbie's use of a casual register help her win the trust of her audience. 
26 By focusing on directorial choices as well as dialogue, these discussions of the excerpts become more than a simple listening skills activity. They provide the opportunity to increase the number of students actively participating. The fact that attention to visual detail is as important as listening comprehension skills means that more people are drawn into the exchange. Not only do the students who have understood the dialogues respond to the questions, others who have weaker aural comprehension skills but who have picked up on directorial choices can also make valid contributions. It is the combined efforts of the students who have understood the spoken dialogues and those who have noticed cinematic devices that allow the class to capture the entirety of the film's message in all its complexity.

3.3. During the last half-hour of the course, students use the language and knowledge consolidated during the practice stages for authentic production by exploring the subprime crisis in greater detail. This work takes a variety of forms.

28 - Role plays: A number of role plays are outlined in the students' brochure. For each scenario a list of characters is set, a situation is defined and each character is given a goal. The roles are all based on people whose work or actions have been previously discussed in class. They include characters from the movie/book, academics (e.g. Stiglitz, Shiller), historical figures from the crisis (e.g. Greenspan), journalists (e.g. Amanpour, Taibbi) or average Americans who were affected by the crisis. The short descriptions in the brochure provide students with a starting point to develop talking points for these discussions. In the early weeks of the course these dialogues are improvised by the students in small groups. In later sessions they are taken into account in the overall assessment.

29 - Information gaps: Although most of the information gap activities included in the course belong to the practice stage, during the lesson on speculative bubbles, an information gap activity that produces authentic language is also proposed. The lesson explores three historical bubbles: Tulipmania, the Roaring Twenties and the Dot-com bubble. The class is divided into three groups and each one is given a text about one of these bubbles. After reading their text, each group presents the key features of their bubble. The aim is to find the common features in all speculative bubbles. In order to do so, the students can refer to the theoretical frameworks provided by Minsky on the one hand (displacement, boom, euphoria, profit taking and panic) and Shiller on the other ("social mental illness", "price mediated feedback").

30 - Problem-solving activities: A few problem-solving activities are also proposed. For instance, one activity entails comparing prime mortgages and subprime mortgages. Another exercise explores home equity, with students asked to observe the amount of equity a homebuyer would have depending on certain conditions, such as whether the housing market is rising or falling or whether the buyer made a down payment or not. These activities are highly simplified, with no need for instructors to have advanced knowledge of economics or mathematics, so they are easily managed by any language teacher from the department, yet they provide clear illustrations of important points that allow students to better grasp the intricacies of the subprime debacle.

31 Although the basic lesson plan is similar from one week to the next, the structure does not become monotonous thanks to the broad range of activities, themes and teamwork patterns. Yet each lesson builds on the previous one, so language is repeated and consolidated as themes are recycled and examined in greater detail. 


\section{Assessment of learning outcomes}

The students' grade for the semester is split between continual assessment and a final exam, which is an oral exam, with students picking a random question that covers both an economic question and a reflection on the film.

3 Regarding continual assessment, a written midterm exam makes up half the grade while in-class work constitutes the remaining half. The quality of participation in class and preparation of homework are an integral part of the grade. In addition to that grade, each student is evaluated orally in class twice during the semester: once for the student-led homework round-up discussion, once for the role play activity. The grading schemes for these two evaluations are included in the students' brochure.

4 The homework round-up is done in pairs. Guided by the questions in the course brochure, a team of two students leads the discussion of the material assigned for homework. Students are responsible for the written correction as well as the spoken correction. The material must be covered in 20 minutes. This is not a monologue; students must engage in a dialogue, checking understanding and complementing information when necessary.

Table 1: Grading scheme for "Homework round-up"

35

\begin{tabular}{|l|l|l|l|}
\hline no personal prep & insufficient prep & acceptable prep & prep with back-up research \\
0 & $0.5-1-1.5$ & $2-2.5$ & $3-3.5-4$ \\
\hline
\end{tabular}

INTERACTION - Getting the other students to offer additional information

\begin{tabular}{|c|c|c|c|}
\hline $\begin{array}{l}\text { no } \\
\text { interaction } \\
0\end{array}$ & $\begin{array}{l}\text { presentation with a few } \\
\text { questions } \\
0.5-1-1.5\end{array}$ & $\begin{array}{ll}\text { fairly } & \text { satisfactory } \\
\text { interaction } & \\
2-2.5 & \end{array}$ & $\begin{array}{l}\text { very dynamic collective } \\
\text { round-up } \\
3-3.5-4\end{array}$ \\
\hline
\end{tabular}

COMMUNICATION - Paying attention to the other students' needs (repeating, explaining, NOT reading notes etc.)

\begin{tabular}{|l|l|lr|l|}
\hline $\begin{array}{l}\text { Only } \\
\text { reading } \\
\text { notes }\end{array}$ & $\begin{array}{l}\text { attempts to clarify when } \\
\text { necessary; too much dependence } \\
\text { on notes } \\
0.5-1-1.5\end{array}$ & $\begin{array}{l}\text { Repeating and } \\
\text { explaining } \\
\text { asked } \\
\text { when }\end{array}$ & $\begin{array}{l}\text { Anticipating need to } \\
\text { repeat, explain and clarify } \\
3-3.5-4\end{array}$ \\
\hline
\end{tabular}

PRIORITISING - Deciding what is the most useful information / what should be written on the board 0.5 $-7-1.5$

TIMING - Being able to round up the homework discussion in $20 \mathrm{mn} 0$ - 0.5 - 1- 1.5 

takes the form of a talk show, live podcast or informal conversation (as explained above). Students are only allowed a flashcard during their turn (A5 format) limited to key words and short notes. They are not allowed to read from a written transcript. In order to evaluate interaction as well as the student's ability to produce a prepared monologue, at the end of the group's role play, the debate is opened to the class by inviting other students to ask the characters questions or provide comments.

Table 2: Grading scheme for "Role play"

\begin{tabular}{|c|c|c|c|c|}
\hline GRADE & $\begin{array}{l}\text { FLUENCY } \\
\text { PRONUNCIATION }\end{array}$ & $\begin{array}{l}\text { CONTENT } \\
\text { (ORGANISATION, } \\
\text { REGISTER AND } \\
\text { COHESIVENESS) }\end{array}$ & $\begin{array}{l}\text { VOCABULARY } \\
\text { GRAMMAR }\end{array}$ & $\begin{array}{l}\text { NON-VERBAL } \\
\text { COMMUNICATION \& } \\
\text { ABILITY TO ANSWER } \\
\text { QUESTIONS }\end{array}$ \\
\hline 5 & $\begin{array}{l}\text { Virtually faultless, no } \\
\text { mistakes or } \\
\text { hesitations. Interacts } \\
\text { effortlessly and } \\
\text { effectively. } \\
\text { Outstanding } \\
\text { pronunciation and } \\
\text { variety of intonation } \\
\text { patterns. }\end{array}$ & $\begin{array}{l}\text { Content } \\
\text { outstanding, makes } \\
\text { an original and } \\
\text { interesting } \\
\text { contribution to the } \\
\text { subject. } \\
\text { Outstanding } \\
\text { organisation. } \\
\text { Perfect use of } \\
\text { appropriate } \\
\text { register. }\end{array}$ & $\begin{array}{lr}\text { Outstanding range } \\
\text { and choice } & \text { of } \\
\text { vocabulary } & \text { and } \\
\text { grammar; } & \\
\text { appropriate r } & \text { tone; } \\
\text { fully accurate } & \text { and } \\
\text { appropriate use. }\end{array}$ & $\begin{array}{lr}\text { Outstanding } & \text { eye } \\
\text { contact, rapport with } \\
\text { audience r and } \\
\text { partners. Questions } \\
\text { handled rith } \\
\text { complete confidence, } \\
\text { outstanding answers. } \\
\text { No use of notes. }\end{array}$ \\
\hline 4 & $\begin{array}{l}\text { Excellent fluency, } \\
\text { interacts with others } \\
\text { smoothly and } \\
\text { effectively. Excellent } \\
\text { pronunciation with } \\
\text { appropriate variety of } \\
\text { intonation patterns. }\end{array}$ & $\begin{array}{l}\text { Content excellent, } \\
\text { makes an original } \\
\text { and interesting } \\
\text { contribution to the } \\
\text { subject. Excellent } \\
\text { organisation. } \\
\text { Excellent use of } \\
\text { appropriate } \\
\text { register. }\end{array}$ & $\begin{array}{l}\text { Excellent range and } \\
\text { choice of vocabulary } \\
\text { and grammar; } \\
\text { appropriate tone; } \\
\text { fully accurate and } \\
\text { appropriate use. }\end{array}$ & $\begin{array}{lr}\text { Excellent } & \text { eye } \\
\text { contact, rapport with } \\
\text { audience r and } \\
\text { partners. Questions } \\
\text { handled confidently } \\
\text { and appropriately, } \\
\text { excellent answers. } \\
\text { Spontaneous. Little } \\
\text { use of notes. }\end{array}$ \\
\hline 3.5 & $\begin{array}{l}\text { Speech very } \\
\text { confident, hardly any } \\
\text { hesitations; very good } \\
\text { pronunciation with } \\
\text { appropriate variety of } \\
\text { intonation patterns } \\
\text { and almost no errors. }\end{array}$ & $\begin{array}{l}\text { Content very good } \\
\text { and fully } \\
\text { appropriate to the } \\
\text { context. Very good } \\
\text { organisation and } \\
\text { cohesiveness. } \\
\text { good use } \\
\text { register. }\end{array}$ & $\begin{array}{l}\text { Very good range and } \\
\text { choice of vocabulary } \\
\text { and grammar; } \\
\text { appropriater tone; } \\
\text { minor grammatical } \\
\text { errors only. }\end{array}$ & $\begin{array}{lr}\text { Good eye } & \text { contact, } \\
\text { rapport } & \text { with } \\
\text { audience } & \text { and } \\
\text { partners. } & \text { Little } \\
\text { dependency } & \text { on } \\
\text { notes. Questions } \\
\text { handled confidently, } \\
\text { very good answers. } \\
\text { Limited use of notes. }\end{array}$ \\
\hline
\end{tabular}




\begin{tabular}{|c|c|c|c|c|}
\hline 3 & \begin{tabular}{|lr}
\multicolumn{3}{|l}{ Speech confident; few } \\
hesitations; & good \\
pronunciation & with \\
few errors; & possibly \\
monotonous & \\
intonation.
\end{tabular} & $\begin{array}{l}\text { Content relevant } \\
\text { and adequate to the } \\
\text { context; good } \\
\text { organisation and } \\
\text { cohesiveness. Good } \\
\text { use of register. }\end{array}$ & $\begin{array}{l}\text { Good range and } \\
\text { choice of vocabulary } \\
\text { and grammar; a few } \\
\text { major and minor } \\
\text { grammatical } \\
\text { inaccuracies; good } \\
\text { range of structures. }\end{array}$ & $\begin{array}{lr}\text { Good eye } & \text { contact, } \\
\text { rapport } & \text { with } \\
\text { audience } & \text { and } \\
\text { partners. } & \text { Questions } \\
\text { handled } & \\
\text { appropriately, } & \\
\text { generally } & \text { good } \\
\text { answers } & \text { to } \\
\text { unscripted questions. } & \text { Some use of notes. }\end{array}$ \\
\hline 2.5 & $\begin{array}{l}\text { Speech may contain } \\
\text { some hesitations and } \\
\text { pauses. Pronunciation } \\
\text { reasonable but errors } \\
\text { may lead to some } \\
\text { misunderstandings. }\end{array}$ & $\begin{array}{l}\text { Content generally } \\
\text { detailed, though } \\
\text { with some gaps } \\
\text { and/or repetitions; } \\
\text { reasonable } \\
\text { organisation and } \\
\text { cohesiveness; } \\
\text { satisfactory use of } \\
\text { register. }\end{array}$ & $\begin{array}{l}\text { Reasonable choice of } \\
\text { vocabulary and } \\
\text { grammar; occasional } \\
\text { errors may lead to } \\
\text { misunderstanding, } \\
\text { but rarely affecting } \\
\text { overall message. }\end{array}$ & $\begin{array}{l}\text { Reasonable eye } \\
\text { contact, rapport with } \\
\text { audience re and } \\
\text { partners. Questions } \\
\text { handled reasonably, } \\
\text { generally able to } \\
\text { answer unscripted } \\
\text { questions. Use of } \\
\text { notes. }\end{array}$ \\
\hline 2 & \begin{tabular}{|lr} 
Speech often contains \\
hesitations r \\
pauses. \\
errors \\
pronunciation/ \\
intonation, which \\
impede understanding \\
at times.
\end{tabular} & $\begin{array}{l}\text { Content has little } \\
\text { detail, with } \\
\text { noticeable gaps } \\
\text { and/or repetitions; } \\
\text { poor organisation } \\
\text { and cohesiveness. } \\
\text { Inappropriate } \\
\text { register. }\end{array}$ & $\begin{array}{l}\text { Poor choice of } \\
\text { vocabulary and } \\
\text { grammar; narrow } \\
\text { range of grammatical } \\
\text { structures; errors } \\
\text { leading to some } \\
\text { misunderstanding. }\end{array}$ & $\begin{array}{l}\text { Poor eye contact, } \\
\text { rapport. Questions } \\
\text { handled poorly, poor } \\
\text { ability to } \\
\text { comprehend or } \\
\text { answer some } \\
\text { questions posed. } \\
\text { Excessive use of } \\
\text { notes. }\end{array}$ \\
\hline 1.5 & $\begin{array}{l}\text { Speech very slow and } \\
\text { uneven, with frequent } \\
\text { halts; lack of } \\
\text { coherence. } \\
\text { Pronunciation/ } \\
\text { intonation makes it } \\
\text { very difficult for } \\
\text { audience } \\
\text { understand. }\end{array}$ & $\begin{array}{lr}\text { Content } & \text { largely } \\
\text { inappropriate; a lot } \\
\text { of irrelevant } \\
\text { material or not } \\
\text { focussed enough. } \\
\text { Very r poor } \\
\text { organisation. } \\
\text { Inappropriate } \\
\text { register. }\end{array}$ & $\begin{array}{l}\text { Vocabulary and } \\
\text { grammar simple and } \\
\text { repetitive/limited } \\
\text { for the purpose; } \\
\text { frequent errors, } \\
\text { often leading to } \\
\text { misunderstanding. }\end{array}$ & $\begin{array}{l}\text { Very poor eye } \\
\text { contact, rapport and } \\
\text { visual aids. Questions } \\
\text { handled } \\
\text { Excessive use of } \\
\text { notes. }\end{array}$ \\
\hline 1 & \begin{tabular}{|lr} 
Speech not at B level. \\
Pronunciation makes \\
it impossible & for \\
audiences & to \\
understand. &
\end{tabular} & $\begin{array}{l}\text { Content wholly } \\
\text { inappropriate and/ } \\
\text { or not adapted to } \\
\text { correct register. }\end{array}$ & $\begin{array}{l}\text { Vocabulary and } \\
\text { structures not at B } \\
\text { level. }\end{array}$ & $\begin{array}{l}\text { Minimal effort to } \\
\text { communicate, non- } \\
\text { verbal entirely } \\
\text { unsuccessful. Unable } \\
\text { to handle question } \\
\text { session. }\end{array}$ \\
\hline
\end{tabular}

The homework round-ups and role plays are intended to encourage students to go further in their exploration of the themes and events depicted in the film. They are 
evaluated on the quality of the language but also on their attention to detail and the background research carried out to enhance their productions.

\section{Assessment of program}

41 Overall, feedback from students has been positive. Each year the administration at Paris 2 asks students to evaluate their English courses. Participation in these assessments is not compulsory, therefore the significance of the results is questionable; response rates are only about $40 \%$. That being said, favorable feedback on the L3 Economic English course did improve markedly in 2016-2017 following the introduction of the new syllabus. In 2015-2016, when students were asked whether the previous course had helped them to progress in the language of specialty, only $39 \%$ answered positively. That number climbed to $65 \%$ in 2016-2017 following the introduction of the subprime/Big Short course; an additional 23\% responded that the new syllabus had allowed them to achieve some progress. In 2016-2017 only 9\% of students reported that the course did not provide them with skills likely to prove valuable on the job market, whereas that number was $28 \%$ for the previous syllabus.

In addition to providing comprehensive feedback figures, these questionnaires give students the opportunity to transmit comments. One such comment was a request for vocabulary quizzes to be added to the syllabus. As class time is already limited, teachers were reluctant to introduce weekly in-class quizzes, the preference being to use the classroom for more productive activities. Nevertheless, in 2018-2019 supplementary material to the course was made available to students through the university's Moodle platform. The material includes three quizzes centered on lexicon and correct use of key terms. Students can do the quizzes as many times as they wish and check the correct answers. This organizational choice also fits with the aim of encouraging students to become more autonomous learners.

Some of the respondents on the course assessments have also voiced a request for a greater focus on grammar. Currently, two grammar points are dealt with in the course structure: indirect question forms and passive voice. These two points were singled out by the instructors as being coherent with both the course objectives and the wider aims of the Pôle Langues; the structures are essential in a professional setting while, at the same time, linked to correct register use. Asking coherent questions in meetings is an essential workplace skill; the presence of the passive voice in written work can provide a more formal register, while its use in spoken form can create a more diplomatic tone. Nevertheless, the students' request for more extensive grammar practice was given serious consideration. On the one hand, it is true that the students do need to improve their mastery of grammar. On the other hand, not only is class time strictly limited, but the fact that the classrooms are all mixed level groups means that any grammar lesson inevitably runs the risk of leaving a considerable number of students disengaged. Spending time on elementary grammar points often leaves many advanced students disgruntled and bored, while extensive exploration of advanced grammar points can leave the weaker students struggling to follow and demotivated if they are unable to maintain the pace. Once again, the Moodle platform offered the opportunity to provide a partial response to the problem. Links have been provided both to extra practice for the two grammar points explicitly defined within the course syllabus as well as further links to material that will help students to progress on their own, if they so wish. 
Although the solution is imperfect, it does have the advantage of helping the students to locate good quality tools available online.

One last comment made by some students concerns the choice of the subprime crisis as the subject matter for the course. Some of the students not specialized in finance felt that studying the subprime crisis was not relevant to them. Of all the comments made, this was perhaps the most surprising since the course really does go beyond the crisis' purely technical financial aspects. This feedback prompted teachers to highlight the long-term implications of the crisis more explicitly as well as the ethical and social questions raised by the events.

To date, feedback on the course has been positive. Teachers have also reported positive outcomes, most notably improved student autonomy. This outcome has yet to be officially measured, however the very structure of the course depends predominantly on student engagement and less on instructor input. The use of a broad range of materials is appreciated as the variety helps to keep students engaged. The classes tend to be lively, with interest deepening as students begin to grasp the complexity of the underlying issues. While the discussion following the spoken interactions tend to be slightly stilted in the early weeks of the course, they become more lively and thought provoking as the semester progresses. Equally encouragingly, over the course of the semester, the appropriate lexicon is used more and more prominently. Although, the occasional student may still mention banks "according credits" usually a voice from across the room will whisper, "Grant a loan" ("According credits" is a neologism born of the word-for-word translation of the French term.)

\section{BIBLIOGRAPHY}

CRANDALL, JoAnn \& G. Richard TUCKER. 1990. "Content-based instruction in second and foreign languages." In Padilla, A., H.H. FAIRCHILD \& C. VALADEZ (eds.), Foreign Language Education: Issues and Strategies. Newbury Park, CA: Sage.

DÖRNYEI, Zoltán \& Ema USHIODA. 2011. Teaching and Researching Motivation. New York: Routledge. ÉLINE, Marc. 2017. “Le récit semi-autobiographique comme angle d'approche de la culture des milieux de la finance en anglais de spécialité : l'exemple de Liar's Poker”. ASp 71, 123-143.

ESKEY, David E. 1997. “Syllabus design in content-based instruction”. In SNOW, M. A. \& D. A. BRINTON (eds.), The Content-Based Classroom: Perspectives on Integrating Language and Content, 132-141. White Plains, NY: Longman.

GENESEE, Fred. 1994. "Integrating language and content: Lessons from immersion". Educational Practice Reports 11. National Center for Research on Cultural Diversity and Second Language Learning. Washington, DC: Center for Applied Linguistics.

GRABE, William \& Fredericka L. STOLLER. 1997. "Content-based instruction: Research foundations”. In SNOW, M. A. \& D. A. BRINTON (eds.), The Content-Based Classroom: Perspectives on Integrating Language and Content, 5-21. White Plains, NY: Longman. 
KRUGMAN, Paul. 2011. “The conscience of a liberal”. Wall Street Journal, Nov. 8. <http://

krugman.blogs.nytimes.com/2011/11/08/boom-for-whom/?>.

LEWIS, Michael. 2010. The Big Short: Inside the Doomsday Machine. London: Penguin.

MACKAY, Charles. 1995 [1841]. Extraordinary Popular Delusions and the Madness of Crowds. Ware, GB: Wordsworth Editions.

MOHAN, Bernard A. 1990. "LEP students and the integration of language and Content: Knowledge structures and tasks." In SIMICH-DUDGEON, Carmen. (ed.), Proceedings of the First Research Symposium on Limited English Proficient Students' Issues edited, 113-160. Washington, D.C.: Office of Bilingual Education and Minority Language Affairs.

SEARLE, John R. 2010. Making the Social World. Oxford: Oxford University Press.

STIGLITZ, Joseph E. 2010. Freefall: America, Free Markets and the Sinking of the World Economy. New York: Norton.

TAIBBI, Matt. 2010. “Mortgage bubble blamed, ludicrously, on the government". Rolling Stone Magazine online, Nov. 17. <http://www.rollingstone.com/politics/news/mortgage-bubble-blamedludicrously-on-the-government-20101117>.

The Big Short. Directed by Adam McKay. Los Angeles, CA: Paramount Pictures, 2016. DVD.

USHIODA, Ema. 1998. "Effective motivational thinking: A cognitive theoretical approach to the study of language learning motivation.” In ALCón, E. \& V. CODINA ESPURZ, Current issues in English Language Methodology, 77-90. Castelló de la Plana: Publicacions de la Universitat Jaume I.

VAN DER YEUGHT, Michel. 2016. “A proposal to establish epistemological foundations for the study of specialised languages". ASp 69, 41-63.

\section{NOTES}

1. LANSAD stands for "langues pour spécialistes d'autres disciplines", or "languages for specialists of other disciplines." The sector concerns the language courses students need to take when they study in French universities.

2. Plus a 1.5-hour midterm test that is taken outside these hours.

\section{INDEX}

Keywords: Big Short (The), économie, crise des subprimes, module d'apprentissage

\section{AUTHOR}

CLAIRE HEUILLARD

Université Paris 2 Panthéon-Assas. heuillard@aol.com 